\title{
First pollen survey of murundus in the Chapada Diamantina region of the state of Bahia, Brazil
}

Paulino Pereira Oliveira ${ }^{1,2}$, Roy Richard Funch ${ }^{1}$ and Francisco de Assis Ribeiro dos Santos ${ }^{1}$

Received: 27 March, 2014. Accepted: 12 May, 2014

\begin{abstract}
This was a pollen survey, in which we analyzed the sediments and moss polsters of murundus (termite mounds) in the Chapada Diamantina region of the state of Bahia, Brazil. Palynological treatment revealed the presence of 53 pollen types in murundus sediments, of which 23 were related to plants in the semi-arid zone and 30 remained unidentified. In moss polster samples, the pollen assemblage comprised 42 pollen types for which taxonomic affinities were identified and 54 for which they were not. In our comparison of the two pollen assemblages, we found that moss polsters and murundu sediments shared 15 pollen types. For some of the pollen grains in the murundus sediments, it was not possible to make reliable interpretations because of small number of grains and the poor state of conservation. In contrast, the pollen analyses of the moss polster samples showed that they could represent a useful tool for studies of pollen rain. To our knowledge, this is the first study of murundus as natural pollen collectors. Our findings suggest new possibilities for the use of the pollen records preserved in termite mounds.
\end{abstract}

Key words: Palynology, moss polsters, pollen trap, pollen grains

In large areas of northeastern Brazil, huge termite nests in the form of conical mounds, known as murundus, dominate the natural topography of the arid landscape (Funch 1985; Furley 1986; Resende et al. 2004). The murundus are composed primarily of subsurface soils brought to the surface by termite tunneling activity. However, during their construction, they can accumulate pollen grains from the surrounding flora through what is known as "pollen rain" (Moe et al. 2009).

Because of the environmental characteristics of the regions where murundus are found, they offer potential opportunities for paleopalynological studies at arid sites. Pollen preservation in dry or semi-arid environments has presented serious problems for paleobotanists, due to the rapid disintegration of most biological material and the resulting paucity of floristic deposits (Horowitz 1992). However, seemingly unlikely deposition sites can sometimes preserve pollen grains, although these troves are quite unpredictable and generally of poor quality (Traverse 2008). The natural resistance of the large murundus to erosion and weathering might be expected to make them potential sites for pollen grain deposition that could reveal important information about past vegetation types.
In the central and southern regions of the state of Bahia, located in the northeastern region Brazil, there are extensive fields of murundus (Fig. 1). These earth mounds can measure over three meters in height and eight meters in diameter, and their distribution can reach densities exceeding 40 mounds/ha.

This palynological investigation of murundu sediments was motivated by preliminary observations made in the region by Funch (1985), who noted that their composite material remains essentially intact and is not recycled to build new mounds. These murundus appear in areas of semideciduous to deciduous forest (savanna) or caatinga (shrubland), usually originating as small mounds of earth that form around small tree trunks or fallen, decaying wood.

We obtained samples from murundus fields near the towns of Lençóis (12 $33^{\prime} 47^{\prime \prime} S$; $41^{\circ} 23^{\prime} 2^{\prime \prime} \mathrm{W}$ ) and Palmeiras $\left(12^{\circ} 31^{\prime} 4^{\prime \prime} \mathrm{S} ; 41^{\circ} 33^{\prime} 3^{\prime \prime} \mathrm{W}\right)$, both in the Chapada Diamantina region of Bahia. The sediment samples were collected from the tops, lateral flanks, and bases of 12 mounds at different sites, for a total of 36 samples. Some murundus have surface moss polsters, and three samples from these mats (at least 50 $\mathrm{cm}$ above level ground) were included in the pollen analyses.

\footnotetext{
${ }^{1}$ Universidade Estadual de Feira de Santana, Departamento de Ciências Biológicas, Feira de Santana, BA

${ }^{2}$ Corresponding author: paulino.pereira@gmail.com
} 


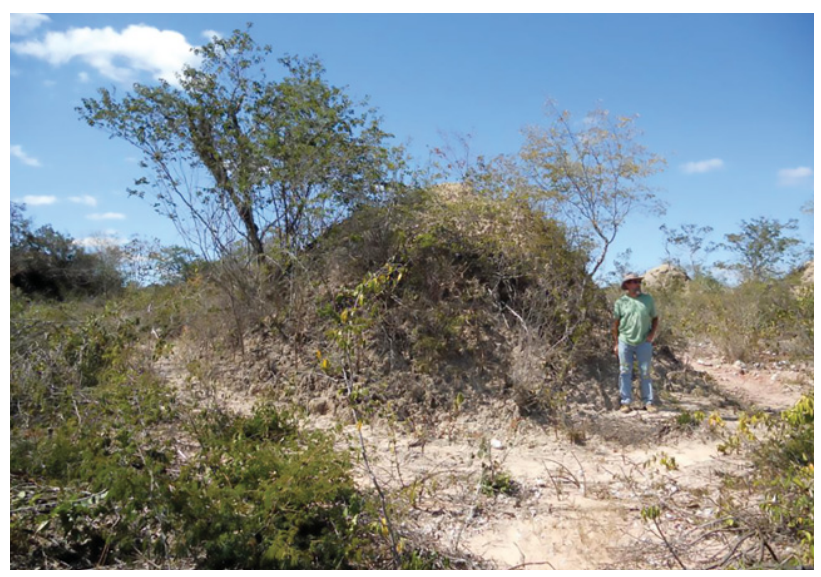

Figure 1. Murundu (termite mound) fields near the town of Lençóis, in the Chapada Diamantina region of the state of Bahia, Brazil.

Sediment samples ( $4 \mathrm{~g}$ ) were taken from each murundu and processed according to the methodology described by Faegri \& Iversen (1975), with the introduction of two tablets of Lycopodium clavatum L. spores (18,583 spores per tablet) to determine pollen concentrations in the samples (Stockmarr 1971). For better separation of pollen grains from the sediments, we also employed flotation with zinc chloride $\left(\right.$ density $\left.=2.1 \mathrm{~g} / \mathrm{cm}^{3}\right)$. Samples were treated with potassium hydroxide (10\%), hydrofluoric acid (40\%), and hydrochloric acid (10\%). The palynological residues were subsequently acetolyzed (Erdtman 1960) and mounted on slides with glycerin jelly for pollen analysis under light microscopy.

The moss polster samples $\left(4 \mathrm{~cm}^{2}\right)$ were processed according to the methodology described by Grabandt (1980). Two tablets of Lycopodium clavatum spores were added to each sample, as described above, after which the samples were boiled in $10 \mathrm{ml}$ of $10 \%$ potassium hydroxide for $10 \mathrm{~min}$. In order to remove the larger plant material fragments, the residues of each sample were passed through a metal sieve $\left(200 \mu \mathrm{m}^{2}\right.$ mesh). Sediments were treated using the acetolysis method, and slides of the pollen grains were prepared, both processes being carried out as described above.

The taxonomic affinities of the pollen grains encountered were determined by comparison with identified samples archived in the pollen library of the Laboratory of Plant Micromorphology at the (Bahia) State University of Feira de Santana. Of the 12 murundus sediment samples, 10 were sterile. In the two samples that were found to contain pollen, and most of the pollen grains were in very poor states of conservation. Those two samples respectively contained ca. 3018 and 88,269 pollen grains per gram. The taxonomic affinities of 23 pollen types were identified, whereas 30 types remained unidentified. In contrast, all three moss polster samples demonstrated good pollen spectra of the current regional vegetation, with pollen concentrations ranging from ca. 12,523 to 74,332 pollen grains per $\mathrm{cm}^{2}$. In the moss polster pollen assemblages, we identified 96 pollen types, among which taxonomic affinities were identified in 42 , and 54 remained unidentified. In addition, we identified more than six types of fern spores. The different pollen types encountered in the moss polsters usually occurred at low frequencies $(<5 \%)$, although eight pollen types occurred at frequencies $>5 \%$ (Tab. 1). In each sample, two or three pollen types were present in greater numbers, those belonging to the families Poaceae and Arecaceae (Syagrus) showing the highest proportions. The moss polsters and murundu sediments were found to share 15 taxonomically identified pollen types (Fig. 2).

Pollen analyses of the murundus sediments indicated that these environments were not ideal for preserving pollen grains, and the records were quantitatively insufficient for paleoecological interpretations or environmental reconstruction. It was also impossible to determine whether the pollen grains had been moved into the mounds (together with the soil particles) by the termites or only superficially deposited onto the murundus by the pollen rain. The analyses of the moss polster samples, however, demonstrated their potential as natural pollen grain collectors for futures studies on temporal vegetation dynamics in the Chapada Diamantina region. The pollen grains present in the $m u-$ rundu sediments were badly damaged, wrinkled, or much degraded, making analyses of their morphological features for taxonomical identification almost impossible.

The methods used for palynological processing of the sample residues (flotation and sieving) did not appear to interfere with the results. Therefore, the absence of pollen grains in the murundu sediments implies either a limited number depositional events or exposure of the grains to environmental conditions that resulted in their degradation during storage. Horowitz (1992) noted two main factors that could affect pollen representation in areas with dry climates. The first is related to the limited amounts of pollen originally produced by the local vegetation that could be incorporated into sediments in those areas, thus reducing the potential available pollen spectrum. The second limiting factor is related to damage to the palynomorphs

Table 1. Taxonomic affinities of the most common pollen grains (frequency $>5 \%$ ) found in moss polsters growing on murundus (termite mounds) in the Chapada Diamantina region of the state of Bahia, Brazil.

\begin{tabular}{lccc}
\hline Pollen types & Sample A & Sample B & Sample C \\
\hline Acanthaceae 1 & $7.5 \%$ & & \\
Forsteronia & & & $6.7 \%$ \\
Mikania & & $5.9 \%$ & \\
Mimosa tenuiflora & & & $5.9 \%$ \\
Poaceae 1 & & & $16.8 \%$ \\
Poaceae 2 & & & \\
Syagrus & $8.8 \%$ & & $5.1 \%$ \\
Thyrsacanthus & $6.2 \%$ & & \\
Numbers of pollen types & 27 & 16 & 28 \\
\hline
\end{tabular}




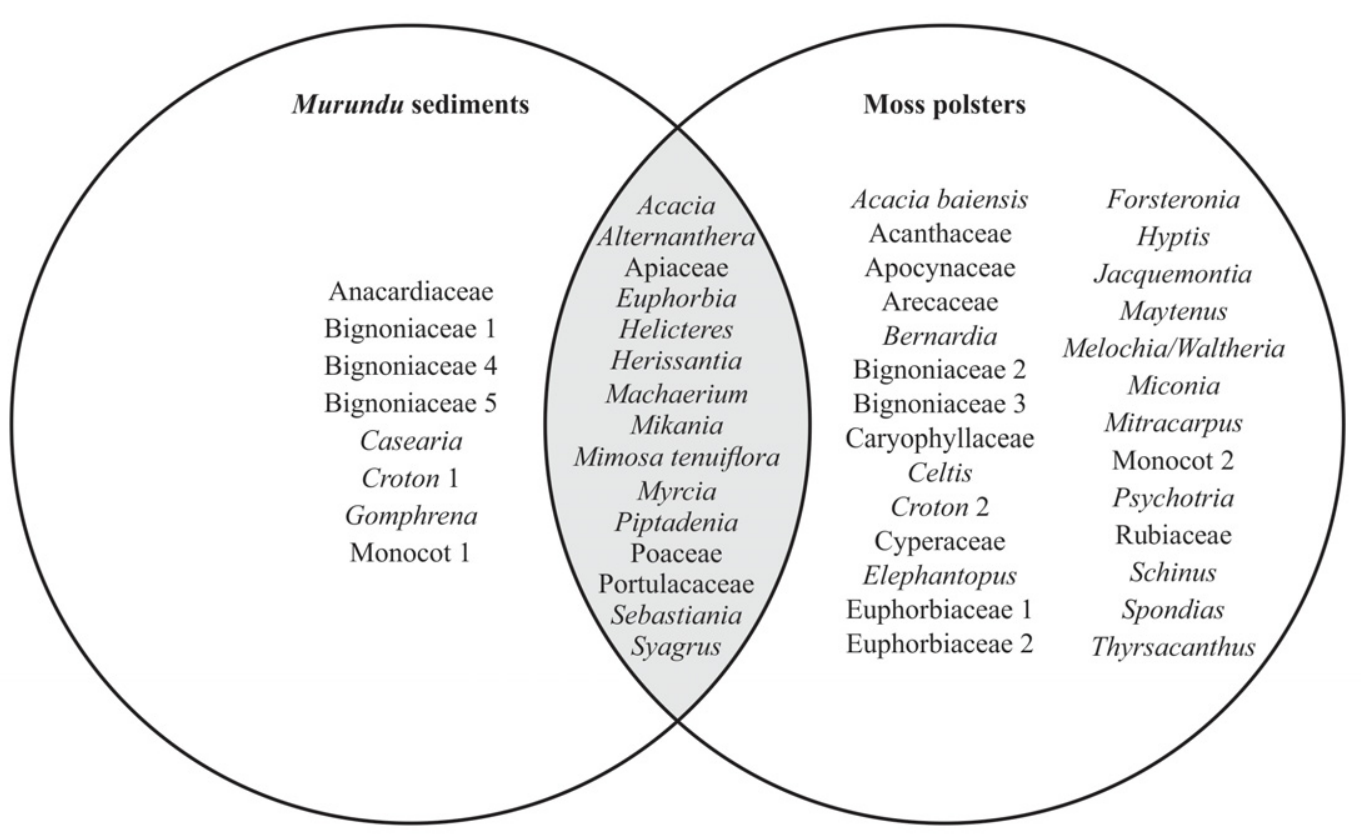

Figure 2. Pollen types present in murundu (termite mound) sediments and moss polsters from the Chapada Diamantina region of the state of Bahia, Brazil. Intersection - pollen types shared by both samples.

by numerous environmental agents during their transport to the deposition site.

The observed differences between the pollen spectra in the murundu sediments and those in the moss polsters can be related to poor pollen preservation in the former, making them unviable for paleoecological studies, in contrast to those obtained from the moss polsters. Wilmshurst \& McGlone (2005) performed palynological analyses on moss polster samples and reported that the palynomorphs encountered were all essentially in excellent states of preservation and in greater amounts than those derived from soil samples. Traverse (2008) showed that pollen grain preservation in sediments is determined by a number of factors, such as the amount of sporopollenin in the pollen wall, the characteristics of the deposition site, and the manner of sedimentation (oxidative conditions being harmful). The most likely reason for the absence of pollen in murundu sediments is the fact that those sediments do not appear to provide an oxygen-free environment for palynomorph preservation, because the termite galleries expose deposited pollen grains to oxidizing conditions.

Considering the low number of pollen grains recorded in the murundus examined and the extremely poor state of preservation of the pollen grains obtained from the sediments, we conclude that the termite mounds studied were not favorable to pollen preservation, precluding their use as a tool in paleopalynological studies of these environments. These findings underscore the idea that $m u$ rundu sediment has a low capacity for pollen preservation. However, the results obtained from the investigation of the moss polsters on some of the murundus were encourag- ing, showing the potential of such natural collectors for studies of pollen rain.

\section{Acknowledgments}

This study received financial support from the Brazilian Conselho Nacional de Desenvolvimento Científico e Tecnológico (CNPq, National Council for Scientific and Technological Development).

\section{References}

Erdtman, G. 1960. The acetolysis method. A revised description. Svensk Botanisk Tidskrift 54: 561-564.

Faegri, K. \& Iversen J. 1975. Textbook of Pollen Analysis. 3.ed. Copenhagen, Munksgaad.

Funch, R.R. 1985. A casa dos "bate-cabeça". Ciência Hoje 4(21): 11.

Furley, P.A. 1986. Classification and distribution of murundus in the cerrado of Central Brazil. Journal of Biogeography 13: 265-268.

Grabandt, R.A.J. 1980. Pollen rain in relation to arboreal vegetation in the Colombian cordillera oriental. Review of Palaeobotany and Palynology, 29: 65-147.

Horowitz, A. 1992. Palynology of arid lands. Amsterdam, Elsevier.

Moe, S.R.; Mobaek R. \& Narmo A.K. 2009. Mound building termites contribute to savanna vegetation heterogeneity. Plant Ecology 202: 31-40

Resende, I.L.M.; Araújo, G.M.; Oliveira, A.P.S. \& Ávila Júnior, R.S. 2004 A comunidade vegetal e as características abióticas de um campo de murundu em Uberlândia, MG. Acta Botanica Brasilica 18(1): 9-17

Stockmarr, J. 1971. Tablets with spores used in absolute pollen analysis. Pollen et Spores, 13(4): 615-621.

Traverse, A. 2008. Paleopalynology. 2. ed. Dordrecht, Springer.

Wilmshurst, J.M. \& McGlone, M,S. 2005. Origin of pollen and spores in surface lake sediments: comparison of modern palynomorph assemblages in moss cushions, surface soils and surface lake sediments. Review of Palaeobotany and Palynology 136: 1-15. 